\title{
Resveratrol alleviates the cytotoxicity induced by the radiocontrast agent, ioxitalamate, by reducing the production of reactive oxygen species in HK-2 human renal proximal tubule epithelial cells in vitro
}

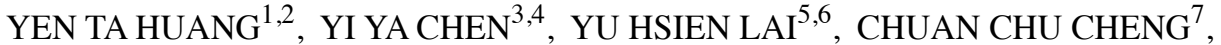 \\ TZU CHUN LIN ${ }^{7}$, YING SHIH SU ${ }^{5,8}$, CHIN HUNG LIU ${ }^{9}$ and PEI CHUN LAI ${ }^{2,10}$ \\ ${ }^{1}$ Surgical Intensive Care Unit, Buddhist Tzu Chi General Hospital; ${ }^{2}$ Department of Medicine \\ and ${ }^{3}$ Master Program in Pharmacology and Toxicology, Tzu Chi University, Hualien; ${ }^{4}$ Department of Nephrology, \\ Da-Yuan Min-Sheng Hospital, Taoyuan; ${ }^{5} \mathrm{PhD}$ Program in Pharmacology and Toxicology, Tzu Chi University; \\ Departments of ${ }^{6}$ Nephrology and ${ }^{7}$ Medical Research, Buddhist Tzu Chi General Hospital, Hualien; \\ ${ }^{8}$ Centers for Disease Control, Ministry of Health and Welfare, Taipei; ${ }^{9}$ Department of Pharmacology, \\ College of Medicine, Tzu Chi University; ${ }^{10}$ Department of Pediatrics, \\ Buddhist Tzu Chi General Hospital, Hualien, Taiwan, R.O.C.
}

Received August 1, 2015; Accepted November 4, 2015

DOI: $10.3892 / \mathrm{ijmm} .2015 .2404$

\begin{abstract}
Radiocontrast-induced nephropathy (RIN) is one of the leading causes of hospital-acquired acute kidney injury (AKI). The clinical strategies currently available for the prevention of RIN are insufficient. In this study, we aimed to determine whether resveratrol, a polyphenol phytoalexin, can be used to prevent RIN. For this purpose, in vitro experiments were performed using a human renal proximal tubule epithelial cell line (HK-2 cells). Following treatment for $48 \mathrm{~h}$, the highly toxic radiocontrast agent, ioxitalamate, exerted cytotoxic effects on the HK-2 cells in a concentration-dependent manner, as shown by MTT assay. The half maximal inhibitory concentration $\left(\mathrm{IC}_{50}\right)$ was found to be approximately $30 \mathrm{mg} / \mathrm{ml}$. Flow cytometry also revealed a marked increase in the number of apoptotic cells following exposure to ioxitalamate. In addition, the number of necrotic, but not necroptotic cells was increased. However, treatment with resveratrol $(12.5 \mu \mathrm{M})$ for $48 \mathrm{~h}$ significantly alleviated ioxitalamate $(30 \mathrm{mg} / \mathrm{ml})$-induced cytotoxicity, by reducing cytosolic DNA fragmentation, increasing the expression of the anti-apoptotic protein, Bcl-2 (B-cell lymphoma 2), and survivin, activating caspase-3, preventing autophagic death and suppressing the production of reactive oxygen species (ROS). Resveratrol also suppressed the ioxitalamate-induced formation
\end{abstract}

Correspondence to: Dr Pei Chun Lai, Department of Pediatrics, Buddhist Tzu Chi General Hospital, 707 Chung Yang Road, Section 3, Hualien 970, Taiwan, R.O.C.

E-mail: chunta.lab@gmail.com

Key words: resveratrol, radiocontrast, ioxitalamate, HK-2, renal proximal tubule epithelial cells of 8-hydroxy-2'-deoxyguanosine (8-OHdG), a biomarker of oxidative DNA damage. N-acetylcysteine (NAC), a ROS scavenger commonly used to prevent RIN, also reduced ioxitalamate-induced cytotoxicity, but at a high concentration of $1 \mathrm{mM}$. Sirtuin (SIRT)1 and SIRT3 were not found to play a role in these effects. Overall, our findings suggest that resveratrol may prove to be an effective adjuvant therapy for the prevention of RIN.

\section{Introduction}

Radiocontrast agents are a type of medical contrast medium which are used when performing computed-tomography or angiography to improve visibility and observe vessels and changes in tissues more clearly. These agents are cleared mainly through glomerular filtration (1). However, these agents are associated with adverse effects, mainly radiocontrast-induced nephropathy (RIN), which is one of the leading causes of hospital-acquired acute kidney injury (AKI), and accounts for approximately $10 \%$ of all causes (2). Some patients may suffer from stage $3 \mathrm{AKI}$ and may thus require dialysis $(3,4)$. Once RIN has developed, the mortality rate increases significantly (4). At least three mechanisms, renal vasoconstriction, increased oxidative stress and direct renal tubular toxicity are known to be involved in the pathophysiology of RIN (5). Clinically, the standard prophylaxis for RIN is intravenous hydration and/or the oral administration of $\mathrm{N}$-acetylcysteine (NAC). Intravenous hydration is mainly used to maintain renal perfusion in order to overcome radiocontrast-induced renal vasoconstriction. However, hydration is contraindicated for some cases, such as congestive heart failure and chronic kidney disease. The antioxidant agent, NAC, acts as free radical scavenger. However, certain meta-analyses and randomized trials have demonstrated 
variable and inconsistent outcomes (6,7). Therefore, the development of a novel strategy for the prevention of RIN is required.

Resveratrol (3,5,4'-trihydroxy-trans-stilbene) is a natural polyphenolic compound found in several plants (e.g., grape skins) (8). The reno-protective effects of resveratrol, particularly those regarding diabetic nephropathy, have been attributed to its antioxidant and anti-inflammatory effects (9). Thus, the aim of the present study was to investigate the protective effects of resveratrol against toxicity induced by the radiocontrast agent, ioxitalamate, in human renal proximal tubule epithelial cells in vitro.

\section{Materials and methods}

Cell and cell culture. The human renal proximal tubule epithelial cell line, HK-2, immortalized by transduction with human papilloma virus 16 (HPV-16) E6/E7 genes, was purchased from the Bioresource Collection and Research Center (BCRC), Hsin-Chu, Taiwan. The HK-2 cells were maintained in keratinocyte serum-free medium (KSFM) supplemented with $5 \mathrm{ng} / \mathrm{ml}$ recombinant epidermal growth factor and $40 \mathrm{ng} / \mathrm{ml}$ bovine pituitary extract (Invitrogen, Carlsbad, CA, USA), and cultured in $5 \% \mathrm{CO}_{2}$ at $37^{\circ} \mathrm{C}$ in a humidified incubator, as previously described (10).

3-(4,5-Dimethylthiazol-2-yl)-2,5-diphenyltetrazolium bromide (MTT) assay. The HK-2 cells were seeded in 96-well plates at $1 \times 10^{4}$ cells/well and used to evaluate cell viability following treatment with ioxitalamate (Telebrix ${ }^{\mathrm{TM}}$; Guerbet, Paris, France) and/or resveratrol (Tocris Bioscience, Minneapolis, MN, USA), NAC (Sigma-Aldrich, St. Louis, MO, USA), necrostatin-1 (Nec-1) (BioVision, Inc., Milpitas, CA, USA), sirolimus and everolimus (both from LC Laboratories, Woburn, MA, USA), and EX-527 and SRT-1720 (both from Selleck Chemicals, Houston, TX, USA). The HK-2 cells were incubated with complete medium at $37^{\circ} \mathrm{C}$ overnight first, then treated with the above-mentioned agent(s) for $48 \mathrm{~h}$. Subsequently, MTT solution (Sigma-Aldrich) was added to each well followed by incubation for $4 \mathrm{~h}$. The supernatant was then removed, and $100 \mu \mathrm{l}$ of dimethyl sulfoxide (DMSO) (J.T. Baker Chemical Co., Phillipsburg, NJ, USA) was added to each well. The absorbance at $565 \mathrm{~nm}$ was measured using an enzyme-linked immunosorbent assay (ELISA) reader and cell viability was calculated according to the following formula: cell viability $=$ (absorbance of the experimental group)/(absorbance of reference group) $x 100$. The reference group was treated with an equal volume of phosphate-buffered saline (PBS) as the control. In some experiments (the cytotoxicity of ioxitalamate plus the autophagy inducers, sirolimus or everolimus, as well as the cytotoxicity of ioxitalamate plus the SIRT1 inhibitor, EX-527, or the SIRT1 activator, SRT-1720), ioxitalamate was considered as the control in order to elucidate the mechanisms involved.

Flow cytometry. Flow cytometry was performed using the Annexin V-FITC apotosis detection kit (BD Biosciences, San Jose, CA, USA). Cell death resulting from either apoptosis or necrosis following treatment with ioxitalamate was analyzed by flow cytometry (BD Biosciences) with conventional protocols (11). The Cyto-ID ${ }^{\circledR}$ autophagy detection kit (Enzo Life
Sciences, Inc., Farmingdale, NY, USA) was used for the staining of autophagic vacuoles, as previously described (12).

DNA damage assay. To evaluate DNA fragmentation in HK-2 cells, the cell death detection ELISA ${ }^{\text {Plus }}$ kit (Roche, Mannheim, Germany) was used. The HK-2 cells were seeded in 12-well plates at $1 \times 10^{4}$ cells/well. The supernatant of the culture medium and cytoplasmic fraction was collected following exposure to ioxitalamate and/or resveratrol for $48 \mathrm{~h}$. To determine the occurence of oxidative DNA damage, the OxiSelect ${ }^{\mathrm{TM}}$ Oxidative DNA Damage ELISA kit (Cell Biolabs, Inc., San Diego, CA, USA) was used for the detection and quantification of 8-hydroxy-2'-deoxyguanosine (8-OHdG).

Reactive oxygen species (ROS) assay. ROS assay was carried out using the OxiSelect ${ }^{\mathrm{TM}}$ Intracellular ROS Assay kit (Cell Biolabs, Inc.). The intensity of green fluorescence is proportional to the levels of ROS production in the cytoplasm of HK-2 cells. The cells were photographed using an Olympus fluorescence microscope (BX43; magnification, x400) with a Panasonic DMC-G1 digital camera following exposure to ioxitalamate and/or resveratrol for $48 \mathrm{~h}$.

Western blot analysis. The HK-2 cells were homogenized in cell lysis buffer (Cell Signaling Technology, Inc., Danvers, MA, USA), and the protein concentrations were determined using the Bio-Rad protein assay kit (Bio-Rad Laboratories, Inc., Hercules, CA, USA). Conventional procedures were followed, as previously described (13). Primary antibodies were purchased from Cell Signaling Technology, Inc. [anti-cleaved caspase-3 (\#9661), anti-survivin (\#2808) and anti-LC3B (\#2775)], and GeneTex [Irvine, CA, USA; anti-B-cell lymphoma 2 (Bcl-2; GTX127958), anti-cellular inhibitor of apoptosis protein (cIAP)1 GTX110087), anti-cIAP2 (GTX113128), anti-B-cell lymphoma-extra large (Bcl-xL; GTX105661), anti-receptor-interacting protein kinase 3 (RIP3; GTX107574), anti-sirtuin (SIRT)1; GTX61042), anti-phospho-SIRT1 (GTX61962) and SIRT3 (GTX89507)]. The expression of $\alpha$-tubulin (sc-8305) (Santa Cruz Biotechnology, Inc., Dallas, TX, USA) or GAPDH (GTX100118; GeneTex) was used as the internal standard. To quantify the changes in protein expression, the levels of intensity were calculated as follows: (immunoreactive intensity of the target protein)/(immuno-reactive intensity of internal control) using NIH software (ImageJ v.1.40).

Statistical analysis. Data were analyzed using the Student's t-test, Mann-Whitney U test, or one-way analysis of variance (ANOVA) based on individual data, and are presented as the means \pm SEM (standard error of the mean). In all cases, a value of $\mathrm{p}<0.05$ was considered to indicate a statistically significant difference.

\section{Results}

Cytotoxic effects of ioxitalamate on $\mathrm{HK}-2$ cells determined by MTT assay. Cell viability following $48 \mathrm{~h}$ of treatment with ioxitalamate is shown in Fig. 1. Cell viability was 80.2 $\pm 2.2,64.2 \pm 2.8$, $51.8 \pm 2.5,38.9 \pm 3.8$ and $31.0 \pm 3.5 \%$ following treatment with $10,20,30,40$ and $50 \mathrm{mg} / \mathrm{dl}$ of ioxitalamate, respectively $(\mathrm{n}=8$ experiments). Ioxitalamate induced significant cell cytotoxicity 


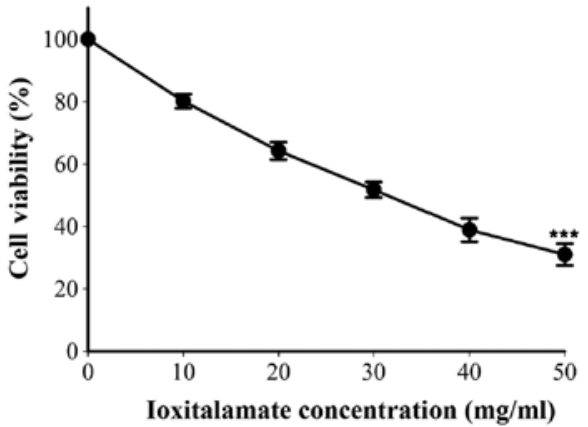

Figure 1. Cytotoxic effects of ioxitalamate on HK-2 cells. The viability of HK-2 cells was measured by MTT assay following treatment with ioxitalamate for 48 h. ${ }^{* * *} \mathrm{p}<0.001$

in a concentration-dependent manner $(\mathrm{p}<0.001$, as shown by one-way ANOVA). Ioxitalamate at $30 \mathrm{mg} / \mathrm{ml}$ was selected for use in our subsequent experiments.

Ioxitalamte induces the apoptosis of $H K-2$ cells. As shown in Fig. 2A, the number of early apoptotic cells (Annexin V-positive/ PI-negative) increased from $2.2 \pm 0.7 \%$ in the controls to $32.0 \pm 3.2 \%$ ( $\mathrm{p}=0.0008, \mathrm{n}=3$ experiments) following treatment with ioxitalamate for $48 \mathrm{~h}$ and reached statistical significance. The number of necrotic cells (Annexin V-negative/PI-positive) also increased from $4.2 \pm 0.6$ in the controls to $7.5 \pm 1.2 \%$ in the ioxitalamate-treated cells, but this increase was not statistically significant $(\mathrm{p}=0.07)$. The number of Annexin V-positive/ PI-positive cells, indicative of necrotic and late apoptotic cells, significantly increased from $1.2 \pm 0.4$ in the controls to $6.1 \pm 1.1 \%$ in the ioxitalamate-treated cells $(\mathrm{p}=0.02)$. The total number of Annexin V-positive cells also significantly increased from $3.3 \pm 1.1$ in the controls to $38.1 \pm 2.1 \%$ in the ioxitalamate-treated cells $(\mathrm{p}=0.0001$; Fig. 2B), while the total number of PI-positive cells increased from $5.3 \pm 0.8$ in the controls to $13.5 \pm 0.2 \%$ in the ioxitalamate-treated cells ( $\mathrm{p}=0.0007$; Fig. 2C). RIP3 is a marker of necroptosis, a programmed form of necrosis contributing to AKI (14). In this study, we did not observe any changes in RIP3 expression, suggesting that necrosis, not necroptosis, had occurred following treatment with ioxitalamate (Fig. 2D). In addition, the necroptosis inhibitor, Nec-1, did not reverse ioxitalamate-induced cytotoxicity $(\mathrm{p}=0.312$, as shown by one-way ANOVA, $n=3$ experiments) (Fig. 2E). Therefore, apoptosis, and not necrosis played a predominant role in ioxitalamate-induced cytotoxicity in HK-2 cells.

Autophagy is also involved in renal protection (15). Thus, in this study, we also determined the autophagic status following treatment with ioxitalamate. Surprisingly, flow cytometric analysis revealed a significantly increased autophagic flux following $48 \mathrm{~h}$ of treatment with ioxitalamate $(\mathrm{p}=0.03, \mathrm{n}=3$ experiments; Fig. 2F). To confirm that this phenomenon was a compensatory result or autophagic death, the cells were treated with the autophagy inducers, sirolimus and everolimus, so-called mammalian target of rapamycin (mTOR) inhibitors, in addition to ioxitalamate for $48 \mathrm{~h}$. Both sirolimus and everolimus (both at $1 \mu \mathrm{M}$ ) significantly aggravated ioxitalamate-induced cytotoxicity ( $\mathrm{p}=0.008$ and 0.01 , respectively; $n=3$ experiments) (Fig. 2G). Therefore, ioxitalamate also induced autophagic death.
Resveratrol alleviates cytotoxicity induced by ioxitalamate in $H K-2$ cells. Cell viability following $48 \mathrm{~h}$ of treatment with ioxitalamate $(30 \mathrm{mg} / \mathrm{ml})$ in combination with resveratrol is shown in Fig. 3. Resveratrol alone did not influence the viability of the HK-2 cells. Ioxitalamate induced significant cytotoxicity in a concentration-dependent manner $(\mathrm{p}<0.001$, as shown by one-way ANOVA, $n=5$ experiments). However, treatment with resveratrol at 12.5 and $25 \mu \mathrm{M}$ increased cell viability from $53.7 \pm 2.8$ to $66.8 \pm 2.1$ and $73.2 \pm 3.2 \%$, respectively $(\mathrm{p}=0.006$ and 0.002 , respectively). The difference in cell viability between treatment with 12.5 and $25 \mu \mathrm{M}$ of resveratrol did not reach statistical significance $(\mathrm{p}=0.14)$. Therefore, resveratrol at $12.5 \mu \mathrm{M}$ was selected for use in subsequent experiments.

Apoptosis and autophagic death induced by ioxitalamate are suppressed by resveratrol. A significant increase in cytosolic DNA fragmentation, indicative of apoptosis, was observed following treatment with ioxitalamate $(30 \mathrm{mg} / \mathrm{ml})$ compared to the controls ( $\mathrm{p}=0.008, \mathrm{n}=5$ experiments). Treatment with resveratrol $(12.5 \mu \mathrm{M})$ significantly suppressed ioxitalamate-induced apoptosis ( $\mathrm{p}=0.008$; Fig. $4 \mathrm{~A})$. A significant increase in DNA fragmentation in the culture medium, indicative of necrosis, was also observed following treatment with ioxitalamate compared to the controls ( $p=0.016$; Fig. 4B). However, the difference in DNA fragmentation in the culture medium of the cells treated with ioxitalamate plus resveratrol and those treated with ioxitalamate alone did not reach statistical significance ( $\mathrm{p}=0.584$; Fig. 4B).

The activation of caspase- 3 plays an important role in apoptosis (16). The expression of cleaved caspase-3, the active form of caspase-3 (both 17 and $19 \mathrm{kDa}$ ) was markedly upregulated following treatment with ioxitalamate for $24 \mathrm{~h}(\mathrm{p}=0.01$, $\mathrm{n}=3$ experiments) and $48 \mathrm{~h}(\mathrm{p}=0.03)$. However, treatment with resveratrol significantly attenuated this increase $(\mathrm{p}=0.0002$ and 0.0004 at 24 and $48 \mathrm{~h}$, respectively) (Fig. 4C and D). Resveratrol also alleviated the ioxitalamate-induced activation of LC3B-II, a marker of autophagy converted from LC3B-I ( $\mathrm{p}=0.0002$ and 0.04 at 24 and $48 \mathrm{~h}$, respectively; $\mathrm{n}=3$ experiments) (Fig. 4E and F).

Changes in the expression of anti-apoptotic proteins following treatment with ioxitalamate and/or resveratrol. Anti-apoptotic proteins [e.g., survivin (17), Bcl-2 (18), cIAP (11), Bcl-xL (19)] play important roles in the death of renal tubule epithelial cells. Following treatment with ioxitalamate for $48 \mathrm{~h}$, the expression of Bcl-2 significantly decreased ( $\mathrm{p}=0.005, \mathrm{n}=3$ experiments); however, resveratrol significantly reversed this decrease in Bcl-2 expression ( $\mathrm{p}=0.01$; Fig. 5A and B). The expression of survivin was significantly downregulated following treatment with ioxitalamate for 24 and $48 \mathrm{~h}(\mathrm{p}=0.008$ and 0.0001 , respectively; $n=3$ experiments); however, resveratrol reversed this decrease in survivin expression at $48 \mathrm{~h}$ of treatment ( $p=0.0004)$ (Fig. 5A and C). The expression levels of cIAP1, cIAP2 and Bcl-xL were not altered following treatment with ioxitalamate and/or resveratrol (Fig. 5A).

Resveratrol alleviates ioxitalamate-induced ROS generation without SIRT1 and SIRT3 activation. The protective effects of resveratrol are mediated through at least two mechanisms, direct antioxidant activity and SIRT1 activation (8). ROS, indicated by green fluorescence from 2 ',7'-dichlorodihydro- 
A
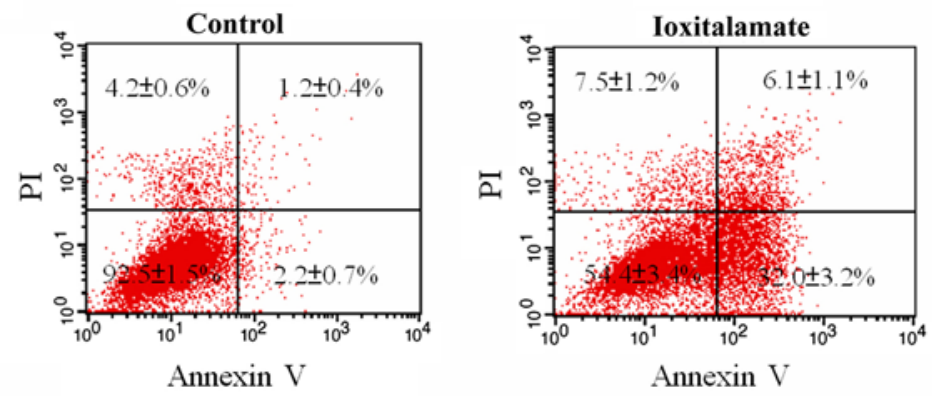

B

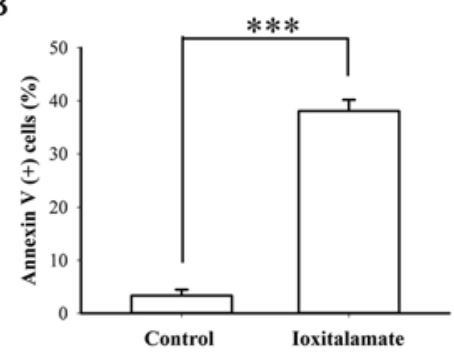

$\mathrm{E}$

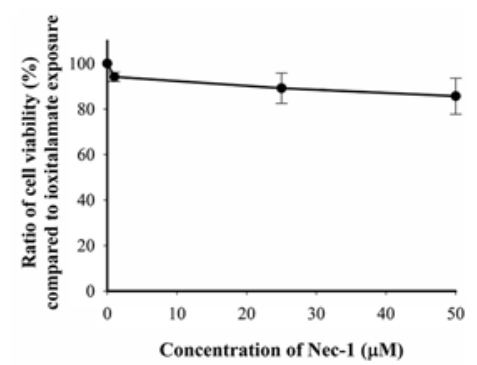

C

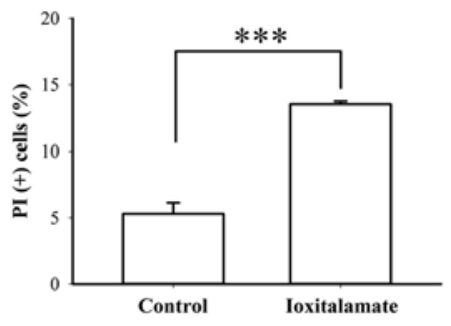

$\mathrm{F}$

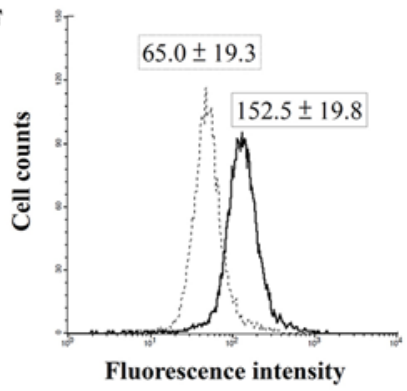

D

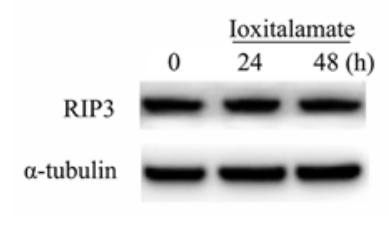

G

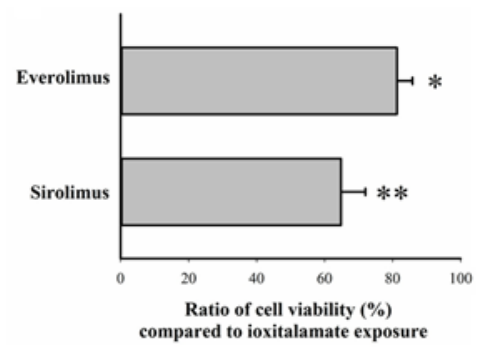

Figure 2. Ioxitalamate-induced cell death patterns in HK-2 cells. Following $48 \mathrm{~h}$ of treatment with $30 \mathrm{mg} / \mathrm{ml}$ ioxitalamate, cell death patterns were determined by various methods. (A) PI and Annexin V staining of HK-2 cells was detected by flow cytometry. Ratio of (B) Annexin V-positive and (C) PI-positive cells by flow cytometry. (D) Representative western blots showing the expression levels of receptor-interacting protein kinase 3 (RIP3), a marker of necroptosis, examined following treatment with ioxitalamate for 24 and $48 \mathrm{~h}$. (E) Compared to treatment with ioxitalamate alone, changes in cell viability were determined following $48 \mathrm{~h}$ of treatment with ioxitalamate plus necroptosis inhibitor necrostatin-1 (Nec-1) by MTT assay. (F) Autophagic flux by Cyto-ID ${ }^{\circledR}$ dye was measured by flow cytometry. Immunofluorescent distribution shown by the solid and dashed line represents treatment with ioxitalamate and the control, respectively. (G) Compared to treatment with ioxitalamate alone, cell viability following $48 \mathrm{~h}$ of treatment with ioxitalamate plus the autophagy inducers, sirolimus or everolimus, was measured by MTT assay. ${ }^{*} \mathrm{p}<0.05,{ }^{* *} \mathrm{p}<0.01$ and ${ }^{* * *} \mathrm{p}<0.005$.

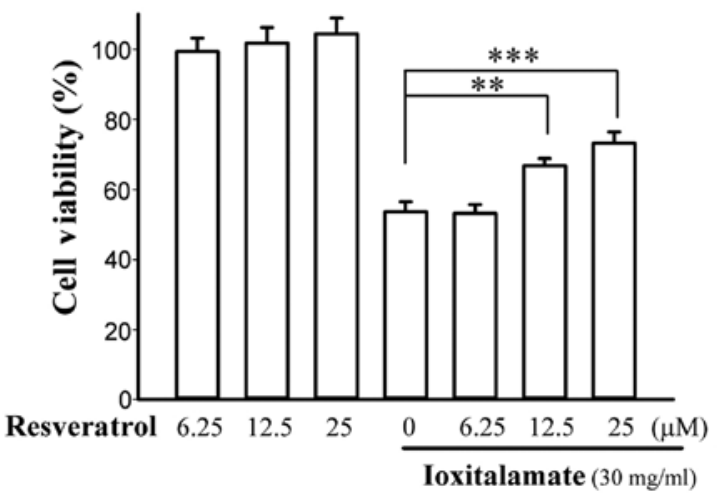

Figure 3. Resveratrol alleviates ioxitalamate-induced cytotoxicity in HK-2 cells. Changes in the viability of HK-2 cells following $48 \mathrm{~h}$ of treatment with ioxitalamate $(30 \mathrm{mg} / \mathrm{ml})$ plus resveratrol at $6.25,12.5$ or $25 \mu \mathrm{M}$ were measured by MTT assay. ${ }^{* *} \mathrm{p}<0.01$ and ${ }^{* * *} \mathrm{p}<0.005$.

fluorescein (DCF), were abundantly generated following treatment with ioxitalamate for $48 \mathrm{~h}$. Resveratrol suppressed the production of ROS induced by ioxitalamate (Fig. 6A). DNA fragmentation may result from oxidative stress (20). Ioxitalamate significantly induced oxidative DNA damage, as shown by the detection of the formation of $8-\mathrm{OHdG}(\mathrm{p}=0.0002$, $\mathrm{n}=4$ experiments; Fig. 6B). However, resveratrol significantly suppressed the ioxitalamate-induced formation of $8-\mathrm{OHdG}$ $(\mathrm{p}=0.01$; Fig. 6B). We also determined the therapeutic effects of the ROS scavenger, NAC. NAC also significantly reduced ioxitalamate-induced cytotoxicity in the HK-2 cells $(\mathrm{p}=0.001$, as shown by one-way ANOVA, $n=3$ experiments) (Fig. 6C). However, a high concentration of $\mathrm{NAC}(1 \mathrm{mM})$ was required to increase cell viability form $52.4 \pm 3.7$ to $70.2 \pm 3.3 \%$.

Furthermore, we examined the expression of SIRT1, which is associated with reno-protection in AKI(21). The expression of SIRT1 and phospho-SIRT1 was not altered following treatment with ioxitalamate and/or resveratrol (Fig. 7A). Resveratrol is also known as a SIRT3 activator (22). Cisplatin-induced tubular damage may result from the downregulation of SIRT3 (23). In our study, SIRT3 was upregulated following treatment with 
A

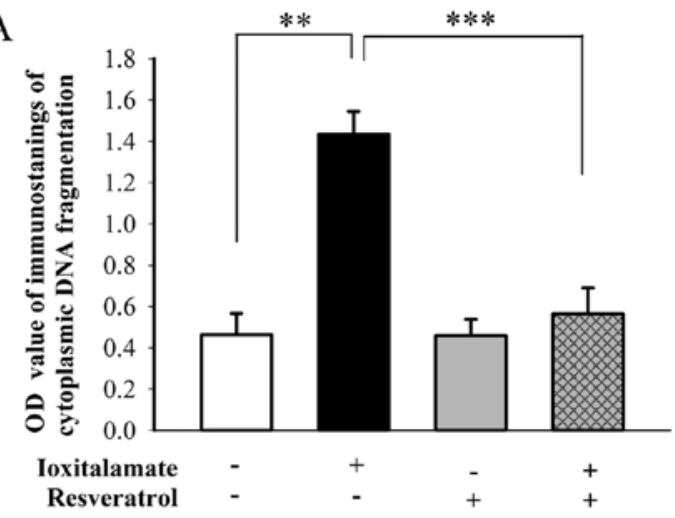

$\mathrm{C}$

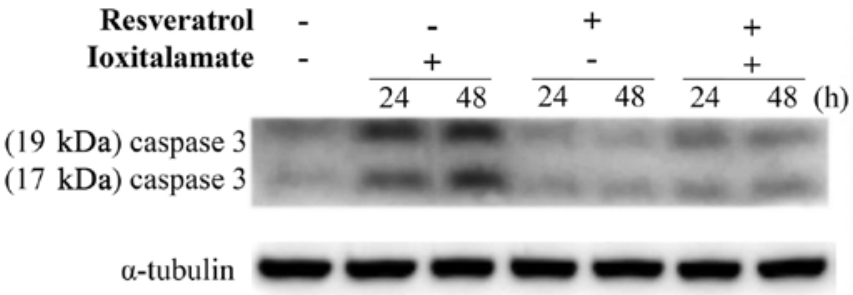

$\mathrm{E}$

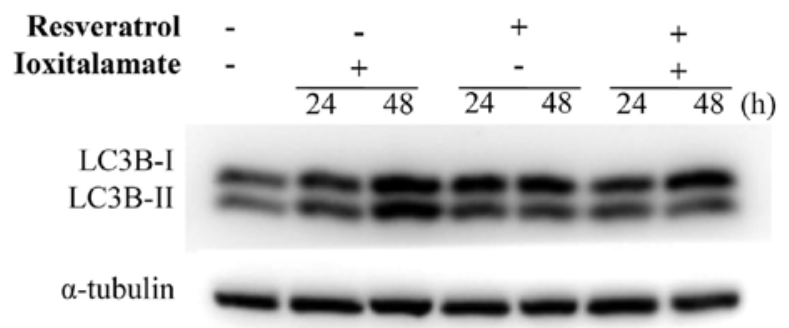

B

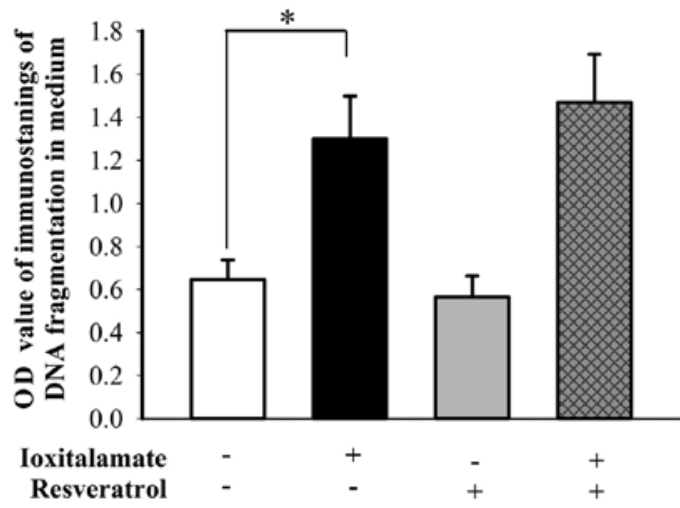

$\mathrm{D}$

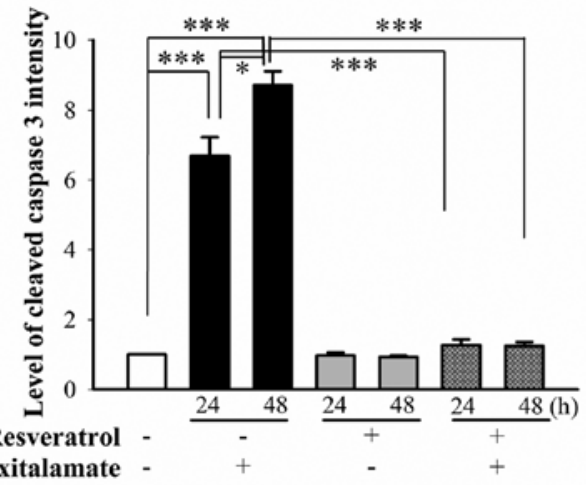

F

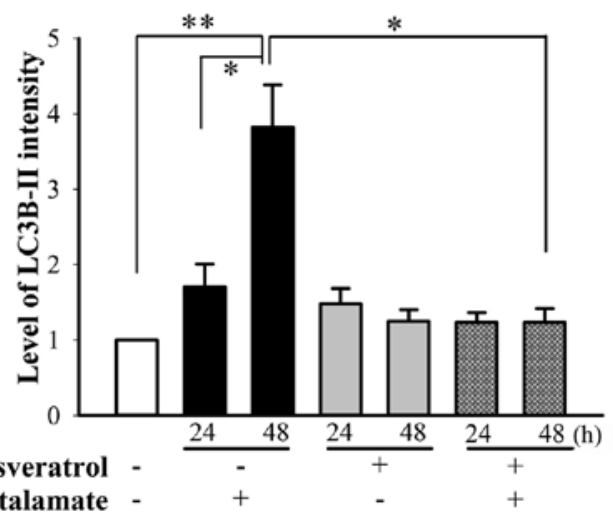

Figure 4. Resveratrol suppresses ioxitalamate-induced apoptosis and autophagy in HK-2 cells. Following treatment with 30 mg/ml ioxitalamate for 48 h, the supernatants of both the culture medium and the cytoplasmic fraction of HK-2 cells were collected. (A) Increased expression in the cytoplasm alone indicates apoptosis, while (B) increased expression of DNA fragments in the medium indicates necrosis due to membrane rupture. (C) Representative western blots of caspase- 3 in HK-2 cells showing the expression levels of caspase- 3 examined following treatment with ioxitalamate $(30 \mathrm{mg} / \mathrm{ml})$ and/or resveratrol (12.5 $\mu \mathrm{M})$ for 24 and 48 h. (D) Immunoreactivity of cleaved caspase-3 was increased following treatment with ioxitalamate for 24 and 48 h, and resveratrol suppressed caspase-3 expression. (E) Representative western blots of LC3B expression levels examined following treatment with ioxitalamate (30 mg/ml) and/or resveratrol $(12.5 \mu \mathrm{M})$ for 24 and $48 \mathrm{~h}$. (E) Immunoreactivity of LC3B-II, the active form of autophagy, was increased following $48 \mathrm{~h}$ of treatment with ioxitalamate, and resveratrol diminished its expression. ${ }^{*} \mathrm{p}<0.05,{ }^{* *} \mathrm{p}<0.01$ and ${ }^{* * * *} \mathrm{p}<0.005$.

ioxitalamate. Following treatment with resveratrol, SIRT3 expression was increased even further. However, there was no difference observed in the expression of SIRT3 between the cells treated with ioxitalamate alone and those treated with ioxitalamate plus resveratrol (Fig. 7A). No changes in cell viability were observed following treatment with the SIRT1 inhibitor, EX-527 ( $\mathrm{p}=0.123$ in one-way ANOVA, $\mathrm{n}=3$ experiments). By contrast, the SIRT1 activator, SRT-1720, reduced cell viability compared to ioxitalamate treatment $(\mathrm{p}<0.001$, as shown by one-way ANOVA, $n=3$ experiments), particularly at a high concentration $(\mathrm{p}=0.002$ and 0.00002 at 2,500 and $5,000 \mathrm{nM}$, respectively) (Fig. 7B). There are no available specific SIRT3 activators and inhibitors. These results indicated that activation of SIRT1 and SIRT3 played no roles in these effects.

\section{Discussion}

The present study demonstrated that the radiocontrast agent, ioxitalamate, exerted cytotoxic effects on HK-2 human renal proximal tubule epithelial cells in vitro. Resveratrol alleviated 
A

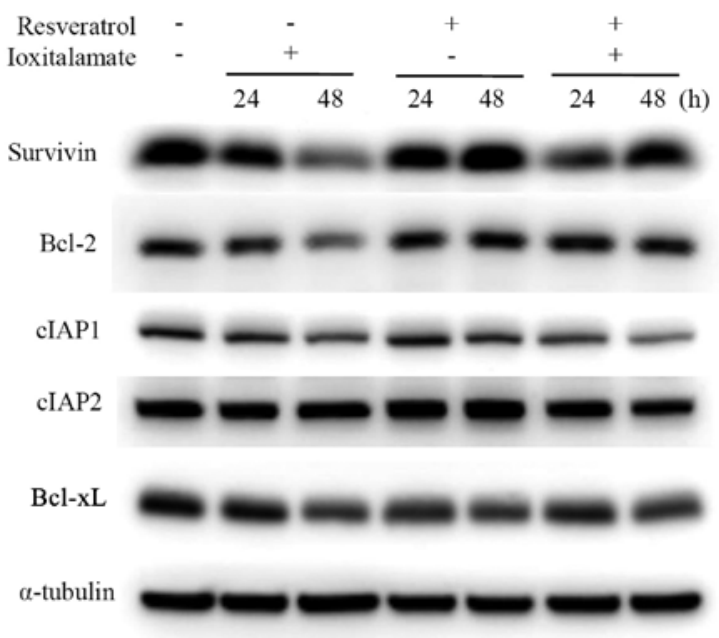

B

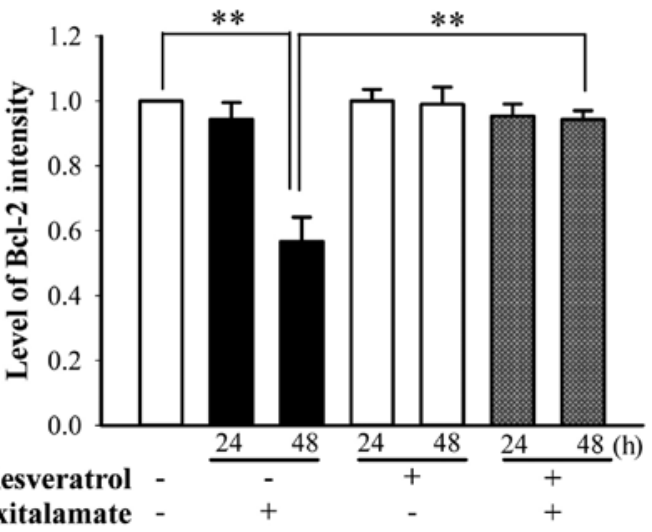

$\mathrm{C}$

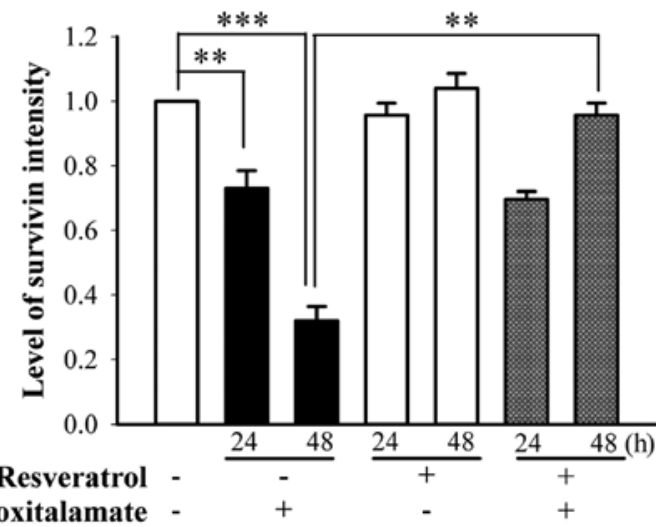

Figure 5. Expression of anti-apoptotic proteins in HK-2 cells following treatment with ioxitalamate and/or resveratrol. (A) Representative western blots of survivin, Bcl-2, cIAP1, cIAP2 and Bcl-xL expression examined following $48 \mathrm{~h}$ of treatment with ioxitalamate and/or resveratrol. (B) Immunoreactivity of Bcl-2 was decreased $48 \mathrm{~h}$ following treatment with ioxitalamate, and resveratrol reversed its expression. (C) Immunoreactivity of survivin was decreased following treatment with ioxitalamate for 24 and $48 \mathrm{~h}$, and resveratrol reversed its expression after $48 \mathrm{~h}$ of treatment. ${ }^{* * *} \mathrm{p}<0.01$ and ${ }^{* * *} \mathrm{p}<0.005$.

ioxitalamate-induced oxidative stress and apoptosis by reversing the downregulation in Bcl-2 and survivin expression. The proximal tubule is particularly vulnerable to extensive damage along the segments by a number of toxins, including radiocontrast agents (24). Ioxitalamate has been reported to exert more
A

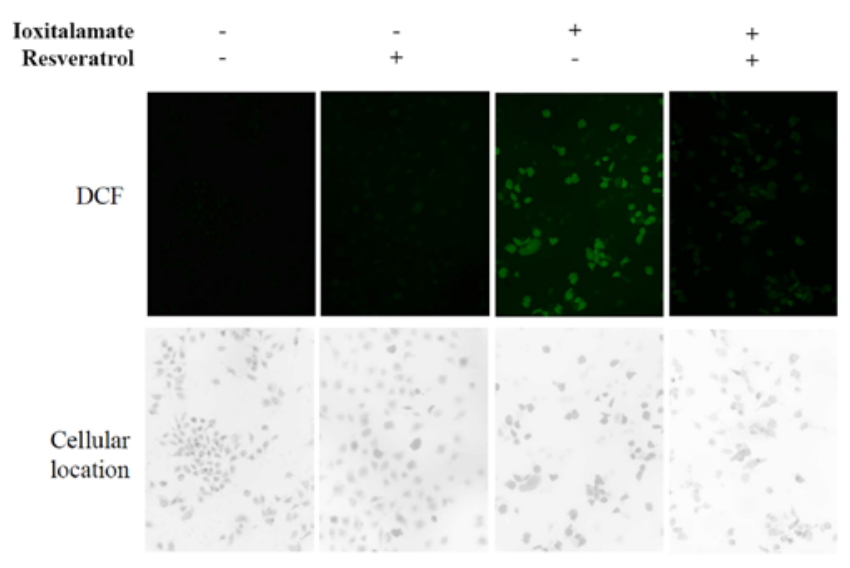

B

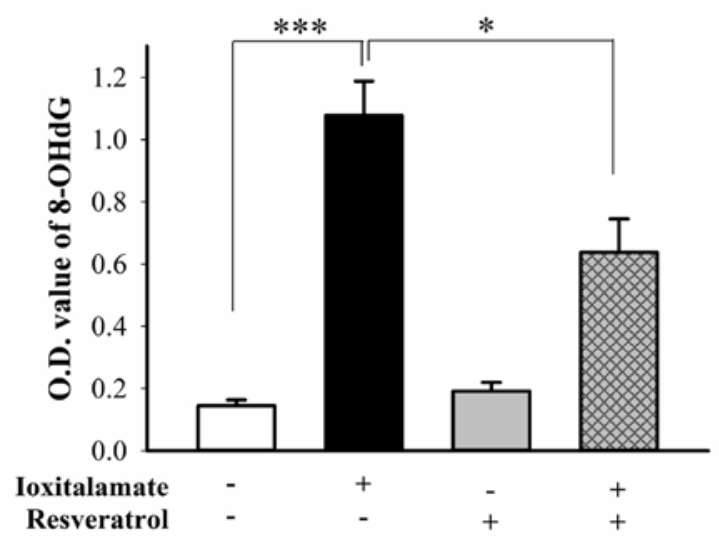

C

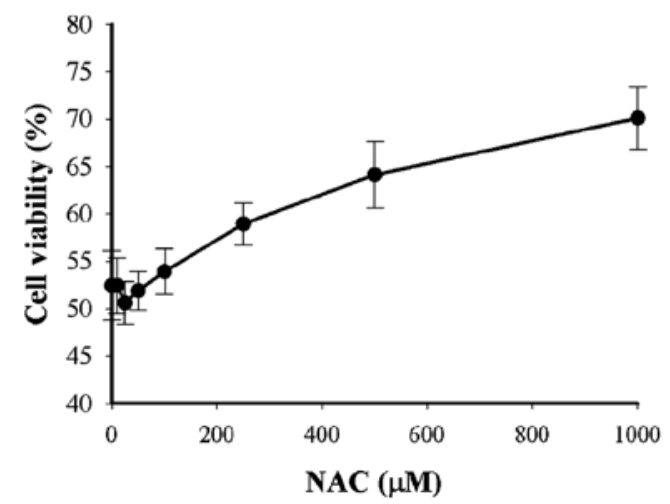

Figure 6. Resveratrol suppresses ioxitalamate-induced reactive oxygen species (ROS) production. (A) Expression of 2',7'-dichlorodihydrofluorescein (DCF), proportional to the ROS level within the cell cytosol, following $48 \mathrm{~h}$ of treatment with ioxitalamate and/or resveratrol (magnification, $\mathrm{x} 400$ ). (B) Formation of 8-hydroxy-2'-deoxyguanosine (8-OHdG), a biomarker of oxidative DNA damage following treatment with ioxitalamate and/or resveratrol. (C) Viability of HK-2 cells was measured by MTT assay following $48 \mathrm{~h}$ of treatment with ioxitalamate plus $\mathrm{N}$-acetylcysteine (NAC). ${ }^{*} \mathrm{p}<0.05$ and ${ }^{* * * *} \mathrm{p}<0.005$.

potent cytotoxic effects than other radiocontrast agents in an in vitro study using the porcine proximal tubular epithelial cell line, LLC-PK1 (25). Ioxitalamate is a high-osmolar ionic monomer radiocontrast agent. In a previous study, iodine alone and hyperosmolar mannitol solution did not elicit significant cytotoxicity on human embryonic kidney (HEK 293) cells, porcine proximal renal tubular (LLC-PK1) and Madin-Darby 


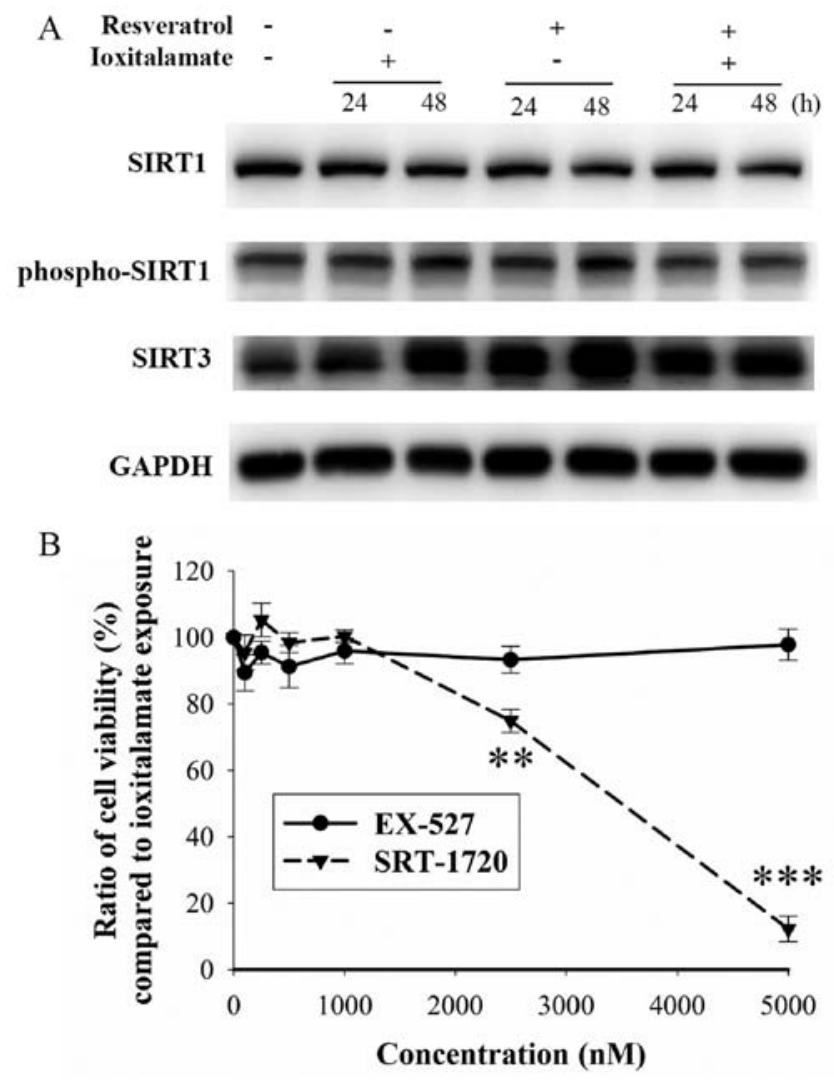

Figure 7. Role of sirtuin (SIRT)1 and SIRT3 in ioxitalamate-induced cytotoxicity. (A) Representative western blots of SIRT1 and phospho-SIRT1 were examined following $48 \mathrm{~h}$ of treatment with ioxitalamate and/or resveratrol. (B) Compared to treatment with ioxitalamate alone, changes in cell viability were examined following $48 \mathrm{~h}$ of treatment with ioxitalamate plus the SIRT inhibitor, EX-527, or the SIRT1 activator, SRT-1720, by MTT assay. ${ }^{* *} \mathrm{p}<0.01$ and ${ }^{* * *} \mathrm{p}<0.005$

canine kidney (MDCK) distal tubular renal cells in vitro (26) However, the HK-2 human renal proximal tubule epithelial cell line is a more suitable model than LLC-PK1 for in vitro toxicity studies to determine drug-induced nephrotoxicity in humans (27). To the best of our knowledge, the investigation of RIN (not ioxitalamate) using HK-2 cells has only been reported in one study to date (28). Therefore, the use of ioxitalamate to examine the therapeutic effects of resveratrol on HK-2 cells is novel.

Not only apoptosis, but also necrosis is induced as a result of cellular damage induced by radiocontrast agents (29). However, no necrosis was noted in the LLC-PK1 in vitro model of RIN (30). Again, the HK-2 in vitro model may be more compatible with the in vivo condition of RIN. In a previous study, necroptosis occurred in a murine ischemia/reperfusion injury-based approach of iomeprol-induced nephropathy, and Nec-1 prevented RIN (31). Liang et al reported that necroptosis contributed to damage to HK-2 cells in an ATP-depleted model (32). However, necroptosis was not observed in this study, and the necroptosis inhibitor, Nec-1, did not reduce ioxitalamate-induced cytotoxicity. If possible, contrast agent-induced necroptosis should be confirmed in human specimens. Besides, perhaps different stimuli cause different patterns of death, even in the same cells. Perhaps the preventive effects of reveratrol against ioxitalamate-induced damage are not sufficient as resveratrol did not prevent the ioxitalamate- induced necrosis. Currently, the most toxic radiocontrast agent, ioxitalamate, is not often used for intravenous infusion. The protective effects of resveratrol, particularly in combination with standard hydration therapy, against the nephrotoxicity induced by other radiocontrast agents should be investigated in the future.

The inhibitor of apoptosis protein, survivin, plays an important role in the regulation of cellular division and survival, particularly in embryonic and cancer cells. Lechler et al examined the expression of survivin in human proximal tubular cells, particularly at the apical membrane (33). In a previous study, the upregulation of survivin expression in renal proximal tubule epithelial cells resulted in the functional and structural recovery of the kidneys from AKI (17). In AKI, the expression of Bcl-2 in proximal renal tubular cells is also decreased, and any management which aims to increase Bcl-2 expression reduces the apoptosis of renal proximal tubule epithelial cells and improves renal function (34). The changes in the immunoreactivity of survivin were more prominent than those of Bcl-2 in our study. This suggests that survivin plays a more important role in the ioxitalamate-induced apoptosis of HK-2 cells. To the best of our knowledge, to date, no agent has been reported to increase both Bcl-2 and survivin expression in AKI. The reverse effects on both Bcl-2 and survivin expression may explain the prominent antiapoptotic effects of resveratrol in our study. In cancer cells, resveratrol has been shown to induce apoptosis through the downregulation of Bcl-2 (35) and survivin (36). It is possible that resveratrol exerts antioxidant effects in normal cells and pro-oxidant effects in cancer cells. One explanation is the 'Warburg effect' (37). The glycolytic pathway is not the primary resource of energy generation and the accumulation of lactate develops in normal cells, promoting physiological $\mathrm{pH}$, to maintain DNA integrity with copper bound to DNA bases hidden in a tight conformation. Resveratrol cannot easily access the protected copper ions and therefore cannot chelate and/or reduce the metal ion in the normal DNA configuration. In cancer cells, the primary energy generating mechanism is the glycolytic pathway that leads to the accumulation of lactate due to the hypoxic environment. Such a low $\mathrm{pH}$ may induce base rotation in DNA, particularly copper bound N7 guanine. Resveratrol then attacks exposed copper, becomes oxidized itself through a copper peroxide mechanism to induce DNA strand breakage in cancer cells (38).

Autophagy, so-called type II cell death, was triggered by RIN in our study. The cell death-promoting role of autophagy has also been shown in renal tubular cells (39). However, autophagy plays a protective role in cisplatin-induced renal tubular damage (40). Autophagy is a double-edged sword (41). The discrepancy among these studies is generally believed to be due to the different experimental conditions used. Autophagy can be either protective or detrimental in renal tubule cells, depending on the different types of injury (15). In this study, ioxitalamate-induced autophagy played a pro-apoptotic role, as the autopahy inducers, sirolimus and everolimus, potentiated ioxitalamate-induced cytotoxicity. By contrast, sirolimus has been shown to alleviate cisplatin induced nephropathy (42). Sirolimus and everolimus bind to FKBP12 and inhibit mTOR, a key regulator of cell proliferation, growth, apoptosis and survival in response to growth factors and cytokines (43). For 
example, sirolimus has been shown to inhibit the growth factorinduced proliferation of renal proximal tubule cells and promote apoptosis by blocking the survival effects of the same growth factors mediated by the inhibition of p70S6k (44). Clinically, the deterioration of renal function has been observed in some patients using mTOR inhibitors (45). To determine the definite role of autohagy in ioxitalamate-induced cytotoxicity, specific genetic approaches, such as the knockdown or transfection of related targets should be used.

Ioxitalamate induces renal tubule cell apoptosis via ROS production (46). The reno-protective effects of resveratrol through antioxidant activity have been also confirmed (8). Thus, it is not surprising that resveratrol alleviated ioxitalamate-induced ROS production in HK-2 cells. To date, the administration of NAC is still the standard treatment used to prevent RIN. Liu et al evaluated 9 randomized trials which suggested that NAC helps to prevent the decline in renal function induced by RIN (47). However, not all of the trials were consistent with the protective effects of NAC. The meta-analysis by Nallamothou et al included 20 trials with 2,195 patients who met the inclusion criteria, but the results were not significant as regards the benefits in patients treated with NAC (48). Perhaps the dosage of NAC used is not sufficient to promote the antioxidant effects in the renal proximal tubule in these clinical studies. Zhang et al demonstrated the cytoprotective effects of NAC at $1 \mathrm{mM}$ against ROS-induced cytotoxicity in HK-2 cells (49), and we found that NAC alleviated ioxitalamate-induced cytotoxicity at the same concentration. Compared to NAC, resveratrol was a robust scavenger of ROS in our study.

Resveratrol is a SIRT activator. However, the expression of SIRT1 was not altered following treatment with $12.5 \mu \mathrm{M}$ resveratrol in the present study. It is reasonable that resveratrol only activates SIRT1 effectively at a concentration $>200 \mu \mathrm{M}$ (50). In addition, no changes in cell viability were observed following treatment with the SIRT1 inhibitor, EX-527, suggesting that SIRT1 does not play a role in ioxitalamate-induced cytotoxicity in HK-2 cells. Beyond the anti-apoptotic effects of SIRT1 via the loss of Ac K382 mark on p53, SIRT1 may also diminish NF- $\mathrm{KB}$ transcription and a decrease in pro-survival gene product in some condition (51). This can explain the fact that the SIRT1 activator, SRT-1720, potentiated ioxitalamateinduced cytotoxicity. Resveratrol indeed activated SIRT3 in the present study, and the concentration was lower than that used in another in vitro study (52). The reason that ioxitalamate upregulated SIRT3 expression in our study remains unknown. The determination of the role of SIRT3 in RIN should be conducted through specific genetic approaches of knockdown or transfection in the future.

In conclusion, the reno-protective effects of resveratrol against ioxitalamate-induced nephropathy was demonstrated by a decrease in ROS production and the suppression of apoptosis in HK-2 human renal proximal tubule epithelial cells. Further in vivo investigations of the therapeutic effects of resveratrol against RIN are warranted in the future.

\section{Acknowledgements}

This study was supported by a Grant-in-Aid from Tzu Chi General Hospital, Hualien, Taiwan, R.O.C.

\section{References}

1. Deray G: Dialysis and iodinated contrast media. Kidney Int Suppl 100: S25-S29, 2006.

2. Tepel M, Aspelin P and Lameire N: Contrast-induced nephropathy: a clinical and evidence-based approach. Circulation 113: 1799-1806, 2006.

3. Lai HM, Aronow WS, Chugh SS, Pudasaini B, Goel A and Garrick R: Risk factors for hemodialysis and mortality in patients with contrast-induced nephropathy. Am J Ther 20: 607-612, 2013

4. Neyra JA, Shah S, Mooney R, Jacobsen G, Yee J and Novak JE: Contrast-induced acute kidney injury following coronary angiography: a cohort study of hospitalized patients with or without chronic kidney disease. Nephrol Dial Transplant 28: 1463-1471, 2013.

5. Wong PC, Li Z, Guo J and Zhang A: Pathophysiology of contrast-induced nephropathy. Int J Cardiol 158: 186-192, 2012.

6. Pattharanitima P and Tasanarong A: Pharmacological strategies to prevent contrast-induced acute kidney injury. BioMed Res Int 2014: 236930, 2014.

7. Quintavalle C, Donnarumma E, Fiore D, Briguori C and Condorelli G: Therapeutic strategies to prevent contrast-induced acute kidney injury. Curr Opin Cardiol 28: 676-682, 2013.

8. Kitada M and Koya D: Renal protective effects of resveratrol. Oxid Med Cell Longev 2013: 568093, 2013.

9. Saldanha JF, Leal VO, Stenvinkel P, Carraro-Eduardo JC and Mafra D: Resveratrol: why is it a promising therapy for chronic kidney disease patients? Oxid Med Cell Longev 2013: 963217, 2013.

10. Ryan MJ, Johnson G, Kirk J, Fuerstenberg SM, Zager RA and Torok-Storb B: HK-2: an immortalized proximal tubule epithelial cell line from normal adult human kidney. Kidney Int 45: 48-57, 1994.

11. Ren X, Han HJ, Lee YJ, Lee SH, Ng HY, Chae KJ and Kim IS: Proapoptotic effect of a micropollutant (tris-(2-chloroethyl)phosphate) at environmental level in primary cultured renal proximal tubule cells. J Water Health 10: 522-530, 2012.

12. Huang YT, Cheng CC, Lin TC, Chiu TH and Lai PC: Therapeutic potential of sepantronium bromide YM155 in gemcitabine-resistant human urothelial carcinoma cells. Oncol Rep 31: 771-780, 2014.

13. Huang YT, Lai PC, Wu CC, Hsu SH, Cheng CC, Lan YF and Chiu TH: BDNF mediated TrkB activation is a survival signal for transitional cell carcinoma cells. Int J Oncol 36: 1469-1476, 2010.

14. Linkermann A, De Zen F, Weinberg J, Kunzendorf U and Krautwald S: Programmed necrosis in acute kidney injury. Nephrol Dial Transplant 27: 3412-3419, 2012.

15. Livingston MJ and Dong Z: Autophagy in acute kidney injury. Semin Nephrol 34: 17-26, 2014.

16. Porter AG and Jänicke RU: Emerging roles of caspase-3 in apoptosis. Cell Death Differ 6: 99-104, 1999.

17. Chen J, Chen JK, Conway EM and Harris RC: Survivin mediates renal proximal tubule recovery from AKI. J Am Soc Nephrol 24: 2023-2033, 2013

18. Suzuki C, Isaka Y, Shimizu S, Tsujimoto Y, Takabatake Y, Ito T, Takahara S and Imai E: Bcl-2 protects tubular epithelial cells from ischemia reperfusion injury by inhibiting apoptosis. Cell Transplant 17: 223-229, 2008.

19. Lorz C, Justo P, Sanz AB, Egido J and Ortíz A: Role of Bcl-xL in paracetamol-induced tubular epithelial cell death. Kidney Int 67: 592-601, 2005.

20. Ott U, Aschoff A, Fünfstück R, Jirikowski G and Wolf G: DNA fragmentation in acute and chronic rejection after renal transplantation. Transplant Proc 39: 73-77, 2007.

21. Hasegawa K, Wakino S, Yoshioka K, Tatematsu S, Hara Y, Minakuchi H, Sueyasu K, Washida N, Tokuyama H, Tzukerman M, et al: Kidney-specific overexpression of Sirt1 protects against acute kidney injury by retaining peroxisome function. J Biol Chem 285: 13045-13056, 2010.

22. Chen Y, Fu LL, Wen X, Wang XY, Liu J, Cheng Y and Huang J: Sirtuin-3 (SIRT3), a therapeutic target with oncogenic and tumor-suppressive function in cancer. Cell Death Dis 5: e1047, 2014.

23. Morigi M, Perico L, Rota C, Longaretti L, Conti S, Rottoli D, Novelli R, Remuzzi G and Benigni A: Sirtuin 3-dependent mitochondrial dynamic improvements protect against acute kidney injury. J Clin Invest 125: 715-726, 2015.

24. Heyman SN, Brezis M, Epstein FH, Spokes K, Silva P and Rosen S: Early renal medullary hypoxic injury from radiocontrast and indomethacin. Kidney Int 40: 632-642, 1991. 
25. Heinrich MC, Kuhlmann MK, Grgic A,Heckmann M,Kramann B and Uder M: Cytotoxic effects of ionic high-osmolar, nonionic monomeric, and nonionic iso-osmolar dimeric iodinated contrast media on renal tubular cells in vitro. Radiology 235: 843-849, 2005.

26. Romano G, Briguori C, Quintavalle C, Zanca C, Rivera NV, Colombo A and Condorelli G: Contrast agents and renal cell apoptosis. Eur Heart J 29: 2569-2576, 2008.

27. Gunness P, Aleksa K, Kosuge K, Ito S and Koren G: Comparison of the novel HK-2 human renal proximal tubular cell line with the standard LLC-PK1 cell line in studying drug-induced nephrotoxicity. Can J Physiol Pharmacol 88: 448-455, 2010.

28. Zager RA, Johnson AC and Hanson SY: Radiographic contrast media-induced tubular injury: evaluation of oxidant stress and plasma membrane integrity. Kidney Int 64: 128-139, 2003.

29. Goldenberg I and Matetzky S: Nephropathy induced by contrast media: pathogenesis, risk factors and preventive strategies CMAJ 172: 1461-1471, 2005 .

30. Heinrich MC, Scheer M, Heckmann M, Kuefner MA and Uder M: Iodixanol induces apoptotic and antiproliferative effects but no necrotic cell death in renal proximal tubular cells in vitro. Rofo 181: 349-354, 2009.

31. Linkermann A, Heller JO, Prókai A, Weinberg JM, De Zen F, Himmerkus N, Szabó AJ, Bräsen JH, Kunzendorf U and Krautwald S: The RIP1-kinase inhibitor necrostatin-1 prevents osmotic nephrosis and contrast-induced AKI in mice. J Am Soc Nephrol 24: 1545-1557, 2013.

32. Liang X, Chen Y, Zhang L, Jiang F, Wang W, Ye Z, Liu S, Yu C and Shi W: Necroptosis, a novel form of caspase-independent cell death contributes to renal epithelial cell damage in an ATP-depleted renal ischemia model. Mol Med Rep 10: 719-724, 2014

33. Lechler P, Wu X, Bernhardt W, Campean V, Gastiger S, Hackenbeck T, Klanke B, Weidemann A, Warnecke C, Amann K, et al: The tumor gene survivin is highly expressed in adult renal tubular cells: implications for a pathophysiological role in the kidney. Am J Pathol 171: 1483-1498, 2007.

34. Havasi A and Borkan SC: Apoptosis and acute kidney injury. Kidney Int 80: 29-40, 2011.

35. Pozo-Guisado E, Merino JM, Mulero-Navarro S, LorenzoBenayas MJ, Centeno F, Alvarez-Barrientos A and Fernandez-Salguero PM: Resveratrol-induced apoptosis in MCF-7 human breast cancer cells involves a caspase-independent mechanism with downregulation of Bcl-2 and NF-kappaB. Int J Cancer 115: 74-84, 2005

36. Liu ML and Zhang SJ: Effects of resveratrol on the protein expression of survivin and cell apoptosis in human gastric cancer cells. J BUON 19: 713-717, 2014.

37. Muqbil I, Beck FW, Bao B, Sarkar FH, Mohammad RM, Hadi SM and Azmi AS: Old wine in a new bottle: the Warburg effect and anticancer mechanisms of resveratrol. Curr Pharm Des 18: 1645-1654, 2012.
38. Zheng LF, Wei QY, Cai YJ, Fang JG, Zhou B, Yang L and Liu ZL: DNA damage induced by resveratrol and its synthetic analogues in the presence of $\mathrm{Cu}$ (II) ions: mechanism and structure-activity relationship. Free Radic Biol Med 41: 1807-1816, 2006.

39. Zhao X, Liu G, Shen H, Gao B, Li X, Fu J, Zhou J and Ji Q: Liraglutide inhibits autophagy and apoptosis induced by high glucose through GLP-1R in renal tubular epithelial cells. Int J Mol Med 35: 684-692, 2015.

40. Periyasamy-Thandavan S, Jiang M, Wei Q, Smith R, Yin XM and Dong Z: Autophagy is cytoprotective during cisplatin injury of renal proximal tubular cells. Kidney Int 74: 631-640, 2008.

41. Kreuzaler P and Watson CJ: Killing a cancer: what are the alternatives? Nat Rev Cancer 12: 411-424, 2012.

42. Jiang M, Wei Q, Dong G, Komatsu M, Su Y and Dong Z: Autophagy in proximal tubules protects against acute kidney injury. Kidney Int 82: 1271-1283, 2012.

43. Schmelzle T and Hall MN: TOR, a central controller of cell growth. Cell 103: 253-262, 2000.

44. Lieberthal W, Fuhro R, Andry CC, Rennke H, Abernathy VE, Koh JS, Valeri R and Levine JS: Rapamycin impairs recovery from acute renal failure: role of cell-cycle arrest and apoptosis of tubular cells. Am J Physiol Renal Physiol 281: F693-F706, 2001.

45. Marti HP and Frey FJ: Nephrotoxicity of rapamycin: an emerging problem in clinical medicine. Nephrol Dial Transplant 20: 13-15, 2005.

46. Hsu SP, Tsai TJ and Chien CT: Ioxitalamate induces renal tubular apoptosis via activation of renal efferent nerve-mediated adrenergic signaling, renin activity, and reactive oxygen species production in rats. Toxicol Sci 114: 149-158, 2010.

47. Liu R, Nair D, Ix J, Moore DH and Bent S: N-acetylcysteine for the prevention of contrast-induced nephropathy. A systematic review and meta-analysis. J Gen Intern Med 20: 193-200, 2005.

48. Nallamothu BK, Shojania KG, Saint S, Hofer TP, Humes HD, Moscucci $M$ and Bates ER: Is acetylcysteine effective in preventing contrast-related nephropathy? A meta-analysis. Am J Med 117: 938-947, 2004.

49. Zhang F, Lau SS and Monks TJ: The cytoprotective effect of $\mathrm{N}$-acetyl-L-cysteine against ROS-induced cytotoxicity is independent of its ability to enhance glutathione synthesis. Toxicol Sci 120: 87-97, 2011 .

50. Borra MT, Smith BC and Denu JM: Mechanism of human SIRT1 activation by resveratrol. J Biol Chem 280: 17187-17195, 2005.

51. Yeung F, Hoberg JE, Ramsey CS, Keller MD, Jones DR, Frye RA and Mayo MW: Modulation of NF-kappaB-dependent transcription and cell survival by the SIRT1 deacetylase. EMBO J 23: 2369-2380, 2004.

52. Chen T, Li J, Liu J, Li N, Wang S and Liu H: Zeng M1, Zhang Y and Bu P: Activation of SIRT3 by resveratrol ameliorates cardiac fibrosis and improves cardiac function via the TGF-beta/Smad3 pathwa. Am J Physiol Heart Circ Physiol 308: H424-H434, 2015. 